\title{
Technology and Quality of Road Construction Projects in Kenya: A focus on Contractor's Exposure to Technology in Machakos Sub-County
}

\author{
Caroline Wachuka Muriithi and Mary Nyawira Mwenda
}

ABSTRACT

Road traffic accidents are a menace to a developing country such as Kenya. The National Transport and Safety Authority website records over 57,171 cases of road traffic accidents NTSA [15]. Adopting the root cause analysis technique, it is crucial to determine and to solve the cause of a problem in order to have a permanent solution for it. This study focuses on road construction projects which are the actual onset of road traffic accidents. Occurrences of road traffic accidents are dependent on various factors ranging from the ideology of road construction projects to the operation of a sound or unsound vehicle on the road. Numerous studies have been done to research on the factors influencing quality of road construction projects but little has been done to determine how contractors related factors affect quality of road construction projects. Due to the research gap in the pool of knowledge, this study is aimed at identifying and analyzing how contractor's exposure to technology influences the quality of road construction projects. The study area that was analyzed in this project was Machakos sub-county situated in the Lower Eastern region of Kenya. The study was guided by the objective: to establish influence of contractor's exposure to technology on quality of road construction projects. This study applied Systems theory approach. A descriptive survey research design and a cross-sectional approach was used to collect quantitative data by use of close-ended questionnaires. The total target population was 223 and a calculative formula adopted from Kothari [8] was used to acquire a sample size of 141 respondents. Stratified random sampling technique was applied on the sample size of 141 respondents to classify them into homogenous groups. Questionnaires were used as the main data collection instruments and were issued to the respondents. The gathered data was analyzed using descriptive and inferential statistics with the data being presented descriptively using frequencies and percentages. Pearson's product moment correlation procedure method was used to analyze the inferential statistic data and the results presented. In this study Spearman's was used to measure the degree of association between the independent and dependent variables. On the influence of contractor's exposure to technology, a composite mean of 3.74, standard deviation of 1.028 and a strong correlation value of 0.373 were achieved. The survey elicit conclusion was that quality of road construction projects in Machakos Sub-County was influenced by the independent variable.

Keywords: contractor, quality, road construction projects, technology.
Published Online: January 7, 2021

ISSN: 2507-1076

DOI: $10.24018 /$ ejbmr.2021.6.1.665

\section{Caroline Wachuka Muriithi*}

Master of Arts in Project Planning and Management, University of Nairobi, Kenya.

(e-mail: carolinemuriithi80@gmail.com) Dr. Mary Nyawira Mwenda Lecturer, School of Open and Distance Learning, University of Nairobi, Kenya. (e-mail: mmwenda@uonbi.ac.ke)

*Corresponding Author

\section{INTRODUCTION}

Road traffic accidents have been a major public outcry for a very long time now, thousands of citizens have reported to have lost their physical mobility, mental state and worse their lives as a result. A report by the NTSA shows that approximately 57,171 , of Kenyan citizens were involved in traffic road accidents between the years, 2016 and April 2020[15]. Approximately 13,473 people during the same period, deaths were experienced resulting from road traffic accidents. This goes without saying, the country is losing a lot of citizens to maiming or deaths as a result of road traffic accidents (RTA). There are various causes of RTA, they include: drivers' factors, vehicle factors and roadway factors. Drivers' factors are the human related choices and decisions that lead to RTA. Thorough trainings and improved human culture can play a key role in improving these factors. Vehicle factors in this case involves the mechanical vehicle conditions that may play as a contributor of RTA. This can be managed by ensuring regular vehicle maintenance, and adhering to the regulations by the government such as one underway to prohibit importation of second hand vehicles above five years from the date of manufacture. A roadway factor involves the condition and state of the road that may lead to any form of RTA. This report focused on the last category, the roadway factors. 
Root cause analysis (RCA) is a scientific technique used to establish the various causes of emerging problems. In this regard, it is only prudent to visit the major causes of RTA, and the factors contributing to these causes. Since the contributing factors to be researched on would be too wide and vast, this project majored on roadway factors. This brings the necessity to research on the various contributing factors resulting in RTA right from the conception of the ideology to construct a road to the usage of a mechanically sound or unsound vehicle. Roadway factors, however, gained a vast and wide area of coverage to be researched on and establish causes of RTA, this study majored on a specific stakeholder involved in the construction of roads. By analyzing the influence of the factors affecting these stakeholders on quality of road construction projects, this study aims to add to the pool of knowledge to the fight against rampant RTA in our country Kenya.

Human race has been known to undertake projects as early as the beginning of organized human activities. Projects ranging from small such as hunters planning hunting activities to the large ones such as the construction of the pyramids of Egypt have for a long time been part of human beings. In every typical project, there exist stakeholders. These stakeholders can be grouped in two categories, the internal stakeholders, and the external stakeholders [18]. Infrastructure projects have the internal stakeholders such as the project officers, senior managers, and other employees of the given body of authority among others. The external stakeholders of the project include: the government, suppliers, customers and finally the contractors [18]. All these stakeholders need proper communication methods to facilitate smooth operation of the project for the achievement of a final quality project. Failure to proper communication among these parties threatens the successful completion of a quality project. This, however, among other factors, is not the only cause that threatens the achievement of quality projects. Many factors affecting different stakeholders pose as a challenge towards achieving quality projects. This project study focused on factors affecting contractors that influence quality of road construction projects.

Contractors are one of the major stakeholders in every project. Many factors affecting the contractors contribute to the successful completion of a project. It is important for the project owner to involve a contractor that is well versed, has specialized and has experience in the area of the specific field in question. A study done by Wondimu [19] on the success factors for early contractor involvement in public infrastructure projects in Norway concludes that it is important for a client to hand a project to a contractor who has technical skills and knowledge of the given job. Majority of the interviewees in the study supported the idea of a contractor that has work experience in the given field of area as one of the few factors for considerations for the qualification of the contract.

Locally, the country has witnessed a high rate of infrastructure projects lately ranging from the construction of roads, buildings, drainage structures, power plants among others. There have been some arising interests from foreign investors to Kenyan road construction projects industry [7]. However, a similar high number of project dissatisfaction has been uncovered in a study by Gwayo [4]. Dissatisfaction of clients is a sign that projects are not of high quality and this brings about some negative repercussions such as poor contractor rating, contract violations and to some extend court cases.

In Machakos sub-county, many road construction projects fail to be completed in time resulting in costs overrun. This is evident due to the large number of projects that get completed after their set due date. Majority of these projects surpass the budget and date of completion. In Kariobagi, Machakos sub-county, a bridge was poorly constructed but within two months of completion, the bridge cracked due to poor workmanship by the contractors or by the use of poor construction materials. According to the Kenya Engineer Magazine, some roads have been recorded to have completed with very poor workmanship. This research study aims at investigating the influence of contractor's influence of technology on quality of road construction projects in Machakos sub-county, Kenya.

\section{A. Statement of The Problem}

The RCA (Root Cause Analysis) strategy illustrates that one has to venture into the cause of the problem and solve it rather than masking the symptoms of the problem. It is important to determine how the RTA occur on our roads by first venturing in the construction stage of the projects. Scrutiny of all the stakeholders involved in the projects is crucial in order to understand where the final problem arises from.

An observation by World Bank [20] stated that most of developing countries experience more failures than success in road construction projects. In Kenya, several county governments like Meru, and Kericho among others have successfully implemented various projects within a span of four years. The above mentioned counties have reported up to $12 \%$ positive road construction projects [13]. Out of the 47 counties, a large number of the counties have enormously failed in their various projects due to corruption, inadequate capital, technological challenges, lack of prioritization and lack of community involvement among others. [13]. A study by Wafula [17] found out that financial availability, organization culture and technical skills were among the key factors that influenced implementation of road projects.

This study, therefore, aims to look at the influence of contractor's exposure to technology on quality of road construction projects in Machakos sub-county. The insurgency of issues in the road construction projects of failure up to the tune of $47 \%$, in the counties, prompted the research on the influence of contractor's exposure to technology on quality of road construction projects in Machakos sub-county, Kenya.

\section{B. Objective of TheStudy}

To establish influence of contractor's exposure to technology on quality of road construction projects in Machakos sub-county, Kenya.

\section{ResearchQuestion}

How does contractor's exposure to technology influence quality of road construction projects in Machakos subcounty, Kenya? 


\section{LITERATURE REVIEW}

Quality is the degree of conformance to specifications. The quality of road construction projects can be measured on the degree of the road meeting the expected goal or usage or could be measured on the durability of the road. The NCA [14] is mandated to regulate the construction industry and is used to streamline, overhaul, and control the industry in Kenya. A report by the NCA records that about 16,665 road contractors registered by the body countrywide [14]. The construction industry is highly competitive since barriers to entry are low, companies are similar and information about companies is freely available.

Contractors worldwide have adopted technology by the use of modern machinery such as bull dozers, excavators, compactor rollers among others. This has enabled increased work volume, reduction of construction time and above all, increased overall work quality of the roads with minimal costs.

The use of macadam-mastic asphalt from the year 2007, application of polymer-bitumen binder 60 from the year 2012, and the use of NOVACHIP from the year 2014 are but among the few technologies applied in road construction projects by many contractors in Russia [9]. The use of these new technologies has proved to be wear resistant and acted as noise reduction materials, increased the duration of the service of the road coating and finally the NOVACHIP technology increased the service life of the road and improves road quality by increasing road traction respectively.

The road network is a means of transporting people and goods; it interconnects to other modes of transport and provides access to social and basic services. Roads account for an estimated $93 \%$ freight and passenger services locally [18]. The CS, National Treasury and Planning [1] confirmed that the length of roads paved during the 2018/2019 financial year rose by $14.2 \%$ to $21,295.1 \mathrm{~km}$. Socio-economic and political development are assured when there is an effective road transport network in a country. This creates a supportive environment to do business and trade within and outside the country. It is therefore essential to manage and maintain road and infrastructure which is among the main pillars of achieving Vision 2030.

Minde [10] conducted a study that was channeled to investigate the aspects influencing quality throughout the lifecycle of a road project. The study incorporated quality at different stages such as conceptual stage, designing stage, construction stage, conformance stage and performing stage. The study found out that owner's policy and effective quality management system is a key factor at conceptual stage. The quality of raw material is an important element for consideration in ensuring quality of construction projects. The study mainly focused on the factors influencing quality of the project at different stages regardless of which stakeholder was involved at which stage. Generalizing these factors and having the assumption that they emanate from equal parties is too big a mistake since each factor is dependent on many other factors such as the stakeholders involved, the functions of key stakeholders among others.

Ministry of Transport and Infrastructure is instructed to perform the following functions: National Transport and Infrastructure Development and Policy Management,
Registration of Engineers and Registration of Roads Construction firms among others. Several road management agencies employ inefficient operational procedures in the bureaucratic civil service protocols and lack of transparency in the legal, operational, and structural connections among them [11]. The Kenya Roads Board (KRB) was set out by the Act of KBR in 1999. Its main goal was to coordinate, develop, rehabilitate, and maintain all the roads in Kenya, as well as managing the KRB Fund account. The roads subsector, as an element of the physical infrastructural sector, is expected to make significant contributions towards achieving Vision 2030.

Technology can be described as the relevant techniques utilized to attain the production of goods and services. Karehka[5] postulates that IT technology has given rise to endless opportunities such as today's global economy, online studies at leisure hours, heavy and efficient farm machinery, computer software for structural designs, prototype creation of structures among others.

Graham [3] conducted a study to establish the level of awareness on uses of technology in the construction of agricultural projects in Central Europe. The survey observed that all the agricultural projects were being moved using technology and that each institution had adequate capacity to incorporate modern technological skills. The survey further indicated that in order to reduce time, cost overruns and attain quality projects modern technology should be implemented in road construction projects. It confirms the importance of exposing contractors to appropriate and high level technology in order to increase the quality of the road construction projects. The study focused on establishing the level of awareness of technology in agricultural projects and did not research on how the uses of technology influences quality of agricultural projects. This, therefore, coerced the study on how influence of contractor's exposure to technology on quality of road construction projects.

Technological Infrastructure directly affects the quality of service experienced by international and external users of the system in terms of speed and responsiveness to their requests for information. Business managers and non-literate staff have a hard time in understanding the technology involved in the selection of information and communication technology.

A study to determine the importance of technical resources in the performance of infrastructure projects in Kenya was conducted by Stephene [16] which revealed that no projects can succeed by applying ancient techniques. The study further advocated for the development of efficient and reliable information systems in managing road construction projects after they carried out a study on application of technology in project management. In addition, the study indicated that use of modern technology in business helped in efficient delivery of good roads that meet customer satisfaction. This study asserts that modern techniques prove to be advantageous to projects and thus, the exposure to technology of contractors is a key factor in ensuring quality of road construction projects. The study focused on infrastructure projects in general and did not zero down to road construction projects and the stakeholder involved. This study intends to research on the influence exposure to technology on contractors have on quality of road construction projects. 
Kasau [6] asserts that the road surface condition is a key consideration in RTA occurrence especially at black spot areas. The surface of the road plays a key role during movement and maneuvering of every vehicle and quality roads requires the right traction with the wheel. Different road surfaces are created depending on climatic condition of the area or the physical gradient of the land. This information is put into consideration by the contractors during the construction process. Contractors equipped with the right technology can been able to determine the type of surface course, base course, and subbase the road requires and thus knows the right materials to acquire and in what quantity.

\section{A. Theoretical Framework}

Various theories may apply in regard to Contractor's Exposure to Technology. Systems theory was used in this study and is discussed below.

Systems theory

The study was anchored on Systems theory as postulated by Ludwig von Bertalanffy, 1968. This theory is geared towards ensuring the long terms goals of an organization are achieved as opposed to the short term goals. The theory is critical in terms of observing and ensuring the new and latest technological systems are adopted by the stakeholders involved. It recognizes the behaviors of an organization by continuously depicting the daily activities between the organization and the external environment, which involve input, throughput, output and feedback.

This involves a systematic approach whereby organizational systems receive information or resources as the input. The information or resources are processed within the organization under the throughput stage using the set organizational systems and an output is obtained. The output which considered to be the product of the organization is put into the external environment to be of appropriate use. Feedback about the product is received in order to gauge the suitability of the product and whether the use was met.

This theory can be categorized as a standard of measuring the effectiveness of a system based on its long term growth. The effectiveness of technological systems existing in construction industry can be measured based on its sustainability by the use of this systems theory. A system that is considered effective is one that brings out the dynamic properties and avoids static equilibrium conditions.

\section{B. ConceptualFramework}

The conceptual framework outlines the dependent and independent variables as discussed in the literature review and elaborated in the Fig. 1 below. It assists in understanding how the independent and dependent variables correlate in the study. This relationship is affected by the government regulatory framework which is a moderating variable and was measured in this study.

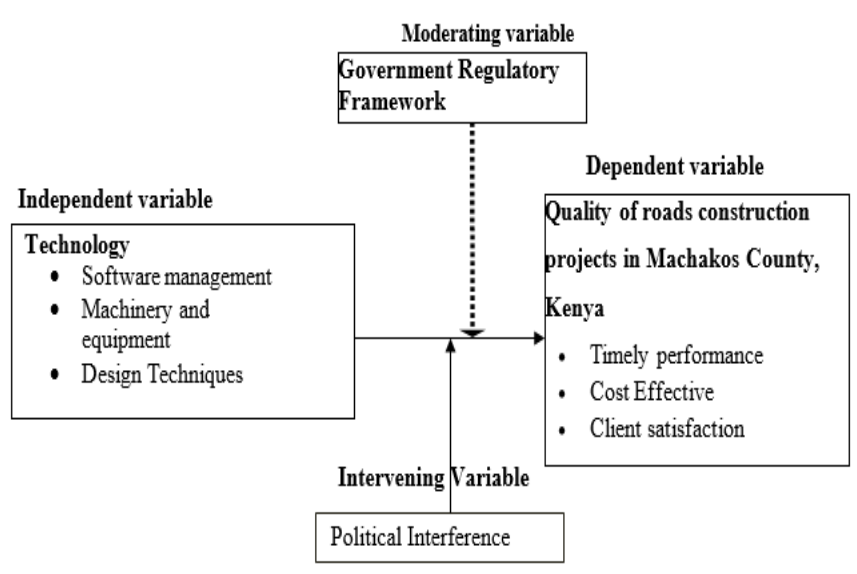

Fig. 1. Conceptual Framework.

\section{RESEARCH METHODOLOGY}

This study employed descriptive survey which was utilized since the problem is well stated and the investigator has a hint on the over laying problem. A survey can be described as the process whereby a situation is studied with the sole aim of explaining why it is that way. This design allowed the accounting and adequate descriptions of activities, objects, and persons. The design type did not only offer descriptions and explanations but also identify and predict relationships in and between the variables of the study.

A Cross-Sectional approach was used to collect quantitative data from the respondents. The approach is relatively fast and inexpensive because it provides selfreported facts about respondents, their feelings, attitudes, opinions, and habits. Descriptive survey design ensures that the researcher understands the existing status of an area of study [21]. This survey design enabled the researcher to make accurate assessment, inferences and relationships of phenomenon, events and issues.

The population of interest in this study was the road contractors, Supervising Engineers and Project officers all in Machakos sub-county. This study targeted 16 Supervising Engineers, 8 project officers at the Machakos sub-county [2] and 199 road contractors registered with National Construction Authority (NCA) in Machakos County [14]. This makes a target population of 223 respondents grouped into three categories.

The choice of a sample size is vital so as to avoid wastage by not being too large and to give confidence to the results of the study by not being too small [8]. A sample population of 141 respondents is arrived at by calculating the target population of 223 with a $95 \%$ confidence level and error of 0.05 using the below formula [8].

$$
n=z^{2} \text {.p.q. } N /\left\{\mathrm{e}^{2}(\mathrm{~N}-1)+\mathrm{z}^{2} \cdot \mathrm{p} \cdot \mathrm{q}\right\}
$$

where

$\mathrm{N}=$ Size of population and given 223 .

$\mathrm{z}=1.96$ (desired confidence level is $95 \%$ and value obtained from table).

$\mathrm{p}=0.5$ (sample proportion).

$\mathrm{q}=0.5\{(1-0.5)$ or $(1-\mathrm{p})\}$.

$\mathrm{e}=5 \%$ or 0.05 (precision rate or acceptable error).

Thus: 


$$
\begin{gathered}
\mathrm{n}=\left\{(1.96)^{2} .(0.5) \cdot(0.5) \cdot 223\right\} /\left\{(0.05)^{2}(223-1)+(1.96)^{2} .\right. \\
(0.5) .(0.5)\} \\
\mathrm{n}=214.1692 / 1.5154=141
\end{gathered}
$$

Purposive sampling was used to select Supervising Engineers and Project officers. A stratified random sampling approach was applied to select road contractors in Machakos sub-county. This was guided by the traffic volume to achieve a reasonable representation of a sample. Stratification can be defined as a process of grouping the whole population into homogenous subgroups before sampling. The strata were mutually exclusive and each element in the population was assigned to a single stratum. The study used a sample of $63.2 \%$ of the target population. Thus, $63.2 \%$ of the accessible population was enough for the sample size.

Primary data was collected by administering semistructured close-ended questionnaires. Closed-ended questions consisted of predetermined answers; these questions collected quantitative data. The questionnaires were pilot tested to determine their suitability to supervising engineers, project officers and contractors. Pilot testing was carried out by purposively selecting 2 projects in Mavoko sub-county, Machakos County and target similar categories of respondents as was done in the main research. The information obtained was used to revise the questionnaire by modifying questions that are sensitive, confusing or biased. The data was analyzed and used to develop dummy tables. The researcher selected representative sample of indicators from the domain of indicators of the concept, then seek expert opinion from the supervisor and another university lecturer to establish the validity of the research instrument. This enhanced the validity of the instruments.

The study used the split-half technique to assess reliability because it has the advantage of eliminating chance errors due to different test conditions. The data was analyzed by the use of Pearson's product moment correlation procedure method. A coefficient of 0.80 was considered an indication of high reliability.

The tool for use in analyzing data was the statistical package for Social Science (SPSS version 22) computer package. The analysis was then done by the use of both descriptive and then inferential statistical methods. The tools for descriptive analysis included frequencies, percentages and other measures of central tendency such as mode, mean and standard deviation. For inferential statistical analysis the tool included Pearson's Product - Moment Correlation. This indicated the level of significance of contractor's exposure to technology and how it influences the quality of the road construction projects.

\section{FINDINGS AND DisCUSSIONS}

\section{A. Background Information of the Respondents}

The researcher administered 141 questionnaires in which 110 were filled and returned. This represents a response rate of $78 \%$ which is considered to be satisfactory to draw conclusion from. This concurs with Mugenda and Mugenda [12] who observed that a $70 \%$ response rate of questionnaire return is very good.
Results in Table 1 show the demographic characteristics

\begin{tabular}{|c|c|c|c|c|}
\hline & & Frequency & Percent & $\begin{array}{c}\text { Cumulative } \\
\text { percent }\end{array}$ \\
\hline \multirow{3}{*}{$\begin{array}{c}\text { Gender of } \\
\text { Respondent }\end{array}$} & Male & 80 & 72.7 & 73.0 \\
\hline & Female & 30 & 27.3 & 100.0 \\
\hline & Total & 110 & 100 & \\
\hline \multirow{5}{*}{$\begin{array}{l}\text { Level of } \\
\text { Education }\end{array}$} & Secondary & 33 & 30.0 & 30.0 \\
\hline & Diploma & 41 & 37.3 & 67.3 \\
\hline & $\begin{array}{c}\text { Bachelor's } \\
\text { degree }\end{array}$ & 26 & 23.6 & 90.9 \\
\hline & $\begin{array}{l}\text { Post- } \\
\text { graduate } \\
\text { degree }\end{array}$ & 10 & 9.1 & 100.0 \\
\hline & Total & 110 & 100 & \\
\hline \multirow{5}{*}{$\begin{array}{l}\text { Age of the } \\
\text { Respondent }\end{array}$} & $\begin{array}{l}30 \text { years and } \\
\text { below }\end{array}$ & 37 & 33.6 & 33.6 \\
\hline & $\begin{array}{c}31-40 \\
\text { years }\end{array}$ & 46 & 41.8 & 74.5 \\
\hline & $41-50$ years & 15 & 13.6 & 88.1 \\
\hline & $\begin{array}{c}\text { Over } 50 \\
\text { years }\end{array}$ & 12 & 10.9 & 100.0 \\
\hline & Total & 110 & 100 & \\
\hline \multirow{5}{*}{$\begin{array}{c}\text { Construction } \\
\text { experience }\end{array}$} & $1-5$ years & 15 & 13.6 & 13.6 \\
\hline & $6-10$ years & 34 & 30.9 & 44.5 \\
\hline & $11-15$ years & 35 & 31.8 & 76.3 \\
\hline & $\begin{array}{c}\text { Above } 15 \\
\text { years }\end{array}$ & 26 & 23.6 & 100.0 \\
\hline & Total & 110 & 100 & \\
\hline \multirow{4}{*}{ Designation } & $\begin{array}{l}\text { Supervising } \\
\text { Engineer }\end{array}$ & 8 & 7.3 & 7.3 \\
\hline & $\begin{array}{l}\text { Project } \\
\text { officer }\end{array}$ & 4 & 3.6 & 10.9 \\
\hline & Contractor & 98 & 89.1 & 100.0 \\
\hline & Total & 110 & 100 & \\
\hline
\end{tabular}
of the respondents:

TABLE I: DEMOGRAPHIC CHARACTERISTIC OF THE SAMPLE

The demographic characteristics of the respondents as shown in Table 1 were as follows: out of the total 110 respondents, $80(73 \%)$ were male while $30(27 \%)$ were female. It is evident that the field is highly dominated by the male gender thus it was nearly impossible to attain the gender rule, however, the research tried to ensure that both genders were fairly represented. With respect to the education level, $23.6 \%$ had attained university level education, $37.3 \%$ had attained diploma, $30 \%$ of the sample population had attained secondary level education and lastly, 9.1\% had attained primary level education.

The gender composition is not expected to have an impact on the statistical power of the data; however, education level determines the respondents' ability to understand the study questions. Approximately, 33\% of the respondents were 30 years and below, $42 \%$ were between $31-40$ years, $13.9 \%$ were between $41-50$ years and $11.1 \%$ recorded over 50 years. The findings were that there are two natural age peaks of the late $20 \mathrm{~s}$ and mid $40 \mathrm{~s}$ which were correlated to implementation of the projects.

The survey shows respondents on road construction projects in Machakos Sub-County, 13.6\% had stayed between 1-5 years, $30.9 \%$ stayed between $6-10$ years, $31.8 \%$ stayed between 11-15 years and 23\% stayed for over 15 years. This indicates that the findings of the study are based on opinions collected from the real respondents who have experience in road construction projects in Machakos SubCounty. Study shows the respondents' composition by designation in the road construction project were as follows, $7.3 \%$ were supervising engineers, $3.6 \%$ were project officer and $89.1 \%$ were contractors. The findings therefore reveal 
that majority of the respondents were fully engaged in the road construction projects in Machakos Sub-County, Kenya.

B. Overall Descriptive Analysis on Contractor's exposure to technology and quality of road construction projects

TABLE 2: CONTRACTOR's EXPOSURE TO TECHNOLOGY AND QUALITY OF ROAD CONSTRUCTION PROJECTS

\begin{tabular}{|c|c|c|c|}
\hline Statement & $\mathrm{N}$ & Mean & SD \\
\hline $\begin{array}{l}\text { Contractors use new modern } \\
\text { software management programs } \\
\text { during construction process }\end{array}$ & 110 & 3.15 & 1.402 \\
\hline $\begin{array}{l}\text { Contractors are well equipped } \\
\text { with modern machinery and } \\
\text { equipment }\end{array}$ & 110 & 3.73 & .985 \\
\hline $\begin{array}{l}\text { The designs and techniques } \\
\text { which contractors use are } \\
\text { effective with no variations }\end{array}$ & 110 & 3.92 & .803 \\
\hline $\begin{array}{l}\text { Contractors and supervising } \\
\text { Engineers are well conversant } \\
\text { with the technology used on the } \\
\text { ground }\end{array}$ & 110 & 3.74 & .874 \\
\hline $\begin{array}{l}\text { The workers have received } \\
\text { training on the latest technology } \\
\text { used worldwide on road } \\
\text { construction projects }\end{array}$ & 110 & 3.70 & 1.097 \\
\hline $\begin{array}{l}\text { Technology used influences the } \\
\text { quality of the road project }\end{array}$ & 110 & 4.22 & 1.008 \\
\hline Composite mean and SD & 110 & 3.74 & 1.028 \\
\hline
\end{tabular}

On statement that Contractors use new modern software management programs during construction process, 20 $(18.2 \%)$ strongly agreed with the statement, $48(43.6 \%)$ agreed, $4(3.6 \%)$ were neutral, $21(19.1 \%)$ disagreed, while $21(19.1 \%)$ strongly disagree with the statement. This line item had a mean score of 3.15 and a standard deviation of 1.402 which was lower than composite mean of 3.74 and standard deviation of 1.028 . This implies that the line item influence quality of road construction projects negatively.

On statement that contractors are well equipped with modern machinery and equipment, 16 (14.5\%) strongly agreed with the statement, 56 (50.9\%) agreed, 24 (21.8\%) were neutral, $4(3.6 \%)$ disagreed, while $6(5.5 \%)$ strongly disagree with the statement. This line item had a mean score of 3.78 and a standard deviation of 0.985 which was higher than composite mean of 3.74 and standard deviation of 1.028 . This implies that the line item influence quality of road construction projects positively. This concurred with the study conducted by Stephene [16] which observed that no projects can succeed by implementing ancient techniques.

On statement that the designs and techniques which contractors use are effective with no variations, 29 (26.4\%) strongly agreed with the statement, $45(40.9 \%)$ agreed, while $34(30.9 \%)$ disagreed with the statement. This line item had a mean score of 3.92 and a standard deviation of 0.803 which was higher than composite mean of 3.74 and standard deviation of 1.028. This implies that the line item influence quality of road construction projects positively.

On statement that Contractors and supervising Engineers are well conversant with the technology used on the ground, $18(16.4 \%)$ strongly agreed with the statement, $58(52.7 \%)$ agreed, $21(19.1 \%)$ were neutral while $13(11.8 \%)$ disagreed with the statement. This line item had a mean score of 3.74 and a standard deviation of 0.874 which was same as the composite mean of 3.74 and standard deviation of 1.028 . This implies that the line item influence quality of road construction projects positively.
On statement that the workers have received training on the latest technology used worldwide on road construction projects, $31(28.2 \%)$ strongly agreed with the statement, 34 $(30.9 \%)$ agreed, $30(27.3 \%)$ were neutral, $11(10.0 \%)$ disagreed, while $4(3.6 \%)$ strongly disagreed with the statement. This line item had a mean score of 3.70 and a standard deviation of 1.097 which was lower than composite mean of 3.74 and standard deviation of 1.028. This implies that the line item influence quality of road construction projects negatively.

On statement that Technology used influences the quality of the road project, $59(53.6 \%)$ strongly agreed with the statement, 27 (24.5\%) agreed, 13 (11.8\%) were neutral, while $11(10.0 \%)$ disagreed with the statement. This line item had a mean score of 4.22 and a standard deviation of 1.008 which was higher than composite mean of 3.74 and standard deviation of 1.028. This implies that the line item influence quality of road construction projects positively.

C. Descriptive Analysis on Quality of Road Construction Projects

Results of analysis of the dependent variable, quality of road construction projects are shown in Table 3.

\begin{tabular}{|c|c|c|c|}
\hline Statement & $\mathrm{N}$ & Mean & SD \\
\hline $\begin{array}{l}\text { The road construction } \\
\text { projects are completed } \\
\text { within set schedules. }\end{array}$ & 110 & 3.66 & 1.052 \\
\hline $\begin{array}{l}\text { The road construction } \\
\text { projects are completed } \\
\text { within set budget. }\end{array}$ & 110 & 3.79 & .959 \\
\hline $\begin{array}{l}\text { Beneficiaries are satisfied } \\
\text { with the project quality. } \\
\text { Road construction projects }\end{array}$ & 110 & 3.70 & .773 \\
\hline $\begin{array}{ll}\text { being } & \text { government } \\
\text { sponsored } & \text { have an }\end{array}$ & 110 & 3.32 & 1.125 \\
\hline $\begin{array}{l}\text { assurance of high quality. } \\
\text { Road construction projects } \\
\text { are similar to any other } \\
\text { government projects. }\end{array}$ & 110 & 3.61 & 1.158 \\
\hline $\begin{array}{l}\text { Contractor related factors } \\
\text { influence the quality of } \\
\text { road construction projects. } \\
\text { Composite mean and SD }\end{array}$ & 110 & 3.83 & 1.116 \\
\hline
\end{tabular}

On statement that the road construction projects are completed within set schedules, $21(19.1 \%)$ strongly agreed with the statement, $53(48.2 \%)$ agreed, 19 (17.3\%) were neutral, $12(10.9 \%)$ disagreed, while 5 (4.5\%) strongly disagreed with the statement. This line item had a mean score of 3.66 and a standard deviation of 1.052 which was higher than composite mean of 3.65 and standard deviation of 1.031 this implies that the line item influence quality of road construction projects positively.

On statement that the road construction projects are completed within set budget, 23 (20.9\%) strongly agreed with the statement, $55(50.0 \%)$ agreed, $22(20.0 \%)$ were neutral, $6(5.5 \%)$ disagreed, while 4 (3.6\%) strongly disagreed with the statement. This line item had a mean score of 3.79 and a standard deviation of 0.959 which was higher than composite mean of 3.65 and standard deviation of 1.031 this implies that the line item influence quality of road construction projects positively.

On statement that the beneficiaries are satisfied with the project quality, $10(9.1 \%)$ strongly agreed with the statement, $66(60.0 \%)$ agreed, $27(24.5 \%)$ were neutral, $5(4.5 \%)$ 
disagreed, while $2(1.8 \%)$ strongly disagreed with the statement. This line item had a mean score of 3.70 and a standard deviation of 0.773 which was higher than composite mean of 3.65 and standard deviation of 1.031 this implies that the line item influence quality of road construction projects positively.

On statement that the Road construction projects being government sponsored have an assurance of high quality, 14 $(12.7 \%)$ strongly agreed with the statement, $44(40.0 \%)$ agreed, $21(19.1 \%)$ were neutral, $25(22.7 \%)$ disagreed, while $6(5.5 \%)$ strongly disagreed with the statement. This line item had a mean score of 3.32 and a standard deviation of 1.125 which was lower than composite mean of 3.65 and standard deviation of 1.031 this implies that the line item influence quality of road construction projects negatively. This is in line with [17] who found that capital availability, organizational culture and technical skills had the greatest influence on the performance of road construction projects.

On statement that the road construction projects are similar to any other government projects, $27(24.5 \%)$ strongly agreed with the statement, $42(38.2 \%)$ agreed, $16(14.5 \%)$ were neutral, $21(19.1 \%)$ disagreed, while $4(3.6 \%)$ strongly disagreed with the statement. This line item had a mean score of 3.61 and a standard deviation of 1.158 which was higher than composite mean of 3.65 and standard deviation of 1.031 this implies that the line item influence quality of road construction projects positively.

On statement that the Contractor related factors influence the quality of road construction projects, 37 (33.6\%) strongly agreed with the statement, 37 (33.6\%) agreed, 19 (17.3\%) were neutral, $14(12.7 \%)$ disagreed, while $3(2.7 \%)$ strongly disagreed with the statement. This line item had a mean score of 3.83 and a standard deviation of 1.116 which was higher than composite mean of 3.65 and standard deviation of 1.031 this implies that the line item influence quality of road construction projects positively.

D. Inferential Analysis of Influence of Contractor's Exposure to Technology and Quality of Road Construction Projects

The measure of strength of a linear association between two variables is determined by the Spearman's productmoment correlation. Spearman's correlation is denoted by $\mathrm{r}$, in this study spearman's was used to measure the degree of association between the independent and dependent variables. The coefficients range from -1 to +1 in which positive values indicate positive correlation and vice versa. Spearman's coefficient that is $r<0.3$ is termed as weak correlation, $0.3>r<0.5$ moderate correlation and $r>0.5$ is termed as strong correlation. The findings showed a correlation coefficient of 0.373 . The study showed a moderate positive correlation between contractor's exposure to technology and quality of road construction project in Machakos Sub-County.

\begin{tabular}{|c|c|c|c|c|c|}
\hline \multirow[t]{2}{*}{ Model } & \multicolumn{2}{|c|}{$\begin{array}{c}\text { Unstandardized } \\
\text { Coefficients }\end{array}$} & \multirow{2}{*}{$\begin{array}{c}\begin{array}{c}\text { Standardized } \\
\text { Coefficients }\end{array} \\
\beta\end{array}$} & \multirow[t]{2}{*}{$\mathrm{t}$} & \multirow[t]{2}{*}{ Sig. } \\
\hline & $\beta$ & $\begin{array}{l}\text { Std. } \\
\text { Error }\end{array}$ & & & \\
\hline (Constant) & .945 & .053 & & .898 & .371 \\
\hline $\begin{array}{l}\text { Contractor's } \\
\text { exposure to } \\
\text { technology }\end{array}$ & .149 & .198 & .084 & .751 & .454 \\
\hline
\end{tabular}

The regression model above has established that taking the independent variable into account notably:

$$
\begin{aligned}
& \left(X_{1}\right) \text { Contractor's exposure to technology. } \\
& Y=\beta 0+B_{1} X_{1}+e \\
& Y=.945+X_{1} .149+.053
\end{aligned}
$$

$\mathrm{Y}$ is the dependent variable (Quality of road construction projects); $\left(\mathrm{X}_{1}\right)$ Contractor's exposure to technology. The result obtained shows that a unit increase in contractor's exposure to technology leads to .149 increase in Quality of road construction projects; From the inferences findings it can be concluded that contractor's exposure to technology influences quality of road construction projects.

\section{CONCLUSION AND RECOMMENDATIONS}

Experts have for a long time advocated for the use of modern technology since it increases the quality of the roads constructed increasing its service life usage thus reduces the costs undertaken from construction stage to maintenance of the roads. This statement has been supported by the research findings since it is evident that the quality of road construction projects in Machakos Sub-County was influenced by contractor's exposure to technology. The response of the respondents show that majority of the line items have a direct influence on the quality of road construction projects.

The study concluded that Contractor's exposure to technology was the leading contractor related factor that influences the quality of road construction projects. The results prove that majority of the respondents agreed that Contractor's exposure to technology influences the quality of road construction projects in Machakos Sub-County.

Based on the survey findings, the survey observed that Contractor's exposure to technology was a major aspect that influenced quality of road construction Project in Machakos Sub-County and the study therefore made following recommendations:

1. There is urgency to enhance Contractor's exposure to technology in the quality of road construction projects. The study recommends Contractors to use new modern software management programs during construction process and workers need to be equipped with the latest technology used worldwide on road construction projects. This will enhance quality of road construction projects.

2. The study recommends adoption of the systems theory to assess the output of the adopted technological systems and gauge the suitability of the system in road construction projects.

3. Further, the current literature reveals that as a future avenue of research, there is urgency to conduct similar research in other devolved county governments and national county government projects in Kenya and other countries in order to determine whether the analyzed aspect can be generalized to influence quality of road construction projects. 


\section{ACKNOWLEDGEMENT}

Glory to God for this far He has brought me, for the knowledge and the opportunity to reach where I have reached. I would also like to acknowledge the assistance given by my supervisor, Dr. Mary Mwenda. This journal article would not have been fully achieved without her support and guidance. I wish to extend my gratitude to the Coordinator UON Machakos center, Mr. Mulwa who encouraged and kept us on the academic track. My husband Charles, my parents, my siblings Joy and Sharon and daughter Diana, supported me throughout my research period. Their understanding and patience cannot be underestimated. Thank you.

\section{REFERENCES}

[1] Cabinet Secretary, National Treasury and Planning (2020). 2020 Economic Survey Report: 28 ${ }^{\text {th }}$ April 2020. 2018 - 2022 State Department for Planning.

[2] Department of Roads and Public Works, (2020). Machakos County Report.

[3] Graham, S. Mohammed, R. Christopple, N. \& Chan, B. (2012). Why Project Teams? Newbury Park, CA: Sage.

[4] Gwayo, A. (2014). A Critical Analysis of the causes pf project Management Failures in Kenya. International Journal of soft Computing and Engineering, 4(1), 64-69.

[5] Karehka, R. (2012). New Business Technology. Retrieved January 31, 2017, from http://www.use of technology.com.

[6] Kasau, M. Prof. Eng. Mang'uriu, G. Dr. Diang’a, S. (2017). Factors that Influence the Incidences of Road Accidents in Kenya: A Survey of Black Spots along Mombasa-Malaba Road. International Academic Journal of Information Sciences and Project Management \begin{tabular}{l|ll} 
(IAJISPM) & ISSN
\end{tabular} http://www.iajournals.org/articles/iajispm_v2_i1_38_65.pdf.

[7] Kenya National Bureau of Statistics (2012). Kenya Facts and Figures. Nairobi, Kenya.

[8] Kothari, C. R. \& Gaurav, G. (2004), Research Methodology, Third Edition, New Age Publishers, New Delhi.

[9] Kovalenko, K. Akhmetshin, M. (2019) The introduction of new technologies in the development and production of roads. Kazan Federal University, Elabuga Institute of KFU, Elabuga, Russian Federation 2Altai State University, Barnaul, Russian Federation. Russia.

[10] Minde, R. (2018). Analyzing The Contractor related factors influencing Quality Throughout the Lifecycle of a Road Project.

[11] Ministry of Transport and Infrastructure, Kenya (2014). The ministry of transport and infrastructure: Government Printers, Kenya.

[12] Mugenda, O. and Mugenda, A. (2003). Research Methods, Quantitative and Qualitative Approaches, Nairobi. Kenya.

[13] Musyoki, Agnes. (2018). Institutional Factors Influencing Implementation of Infrastructure Projects by County Governments in Kenya, A case of Embu county, Kenya.

[14] National Construction Authority (NCA) (2020). http://www.nca.go.ke/.

[15] National Transport and Safety Authority, (2020). http://www.ntsa.go.ke/.

[16] Stephene N. (2013). Effects of Application of Technology in the Performance of Infrastructure Projects in Switzerland. International Journal of Project Management (19); 393-419.

[17] Wafula, E. (2017). Contractor related factors influencing Road Project Performance in Kenya. The University of Nairobi.

[18] Watt, A. (2012). Project Management. Published by BCampus Open Education,

https://opentextbc.ca/projectmanagement/chapter/chapter-5project-stakeholders-project-management/.

[19] Wondimu, P. Hailemichaelc, E. Hosseinia, A. Lohnea, J. Torpa, O. Lædrea, O. (2016). Success factors for early contractor involvement (ECI) in public infrastructure projects. Norwegian University of Science and Technology (NTNU), NO-7491 Trondheim, Norway b Norwegian Public Roads Authority (NPRA), Norway. Elsevier Ltd.

[20] World Bank (2013) World Bank participatory source book. A World Bank Publication, Washington DC.
[21] Zells, L. (2011). Balancing trade-offs in quality, cost, schedule, resources, and risk. Project Management Institute Seminar/Symposium: papers present September 28 to October 2, 1991, 406-411. 